\title{
Rola badań obrazowych układu nerwowego w diagnostyce stwardnienia rozsianego u dzieci
}

\section{Neuroimaging of multiple sclerosis in children}

\author{
Elżbieta Jurkiewicz', Katarzyna Kotulska² \\ IZakład Diagnostyki Obrazowej, Pracownia Rezonansu Magnetycznego, Instyłut „Pomnik - Centrum Zdrowia Dziecka” w Warszawie \\ ${ }^{2}$ Klinika Neurologii i Epileptologii, Instytut „Pomnik - Centrum Zdrowia Dziecka” w Warszawie
}

Neurologia i Neurochirurgia Polska 2011; 45, 2: 152-160

\section{Streszczenie}

Stwardnienie rozsiane (SR) u dzieci od kilku lat budzi coraz większe zainteresowanie. Początki choroby przed 16. rokiem życia stwierdza się nawet u ponad $10 \%$ chorych na SR. Choroba u dzieci przebiega jednak inaczej niż u osób dorosłych, inny jest również obraz badań obrazowych za pomocą rezonansu magnetycznego. $Z$ tych względów SR w pediatrycznej grupie wiekowej wymaga także uwzględnienia odmiennych schorzeń w diagnostyce różnicowej. W ostatnich latach zaproponowano odrębne kryteria rozpoznania SR u dzieci. Ze względu na dużą częstość rzutów, a także duże ryzyko wczesnego rozwoju niepełnosprawności SR u dzieci bardzo ważne jest wczesne prawidłowe rozpoznanie i wdrożenie odpowiedniego leczenia. W niniejszej pracy przedstawiono przegląd aktualnych danych dotyczących epidemiologii, patogenezy oraz diagnostyki obrazowej SR u dzieci.

Słowa kluczowe: stwardnienie rozsiane, dzieci, rezonans magnetyczny.

Stwardnienie rozsiane (SR) to najczęstsza choroba demielinizacyjna ośrodkowego układu nerwowego (OUN). Od kilku lat znacząco rośnie zainteresowanie SR u dzieci. Dziecięca forma SR nie jest chorobą występującą tak rzadko, jak sądzono do tej pory. Liczba

\begin{abstract}
There is an increasing appreciation that multiple sclerosis (MS) can affect children. Up to $10 \%$ of MS patients experience their first symptoms before the age of 16 . The natural history and magnetic resonance imaging of $\mathrm{MS}$ in childhood differ from those observed in adult patients. The differential diagnosis of MS in children should also encompass some paediatric diseases. Recently, the diagnostic criteria for MS in children were published. Due to the high frequency of relapses and the risk of disability at a young age, early diagnosis and treatment of MS in children is very important. This work presents recent data regarding epidemiology, pathogenesis and diagnosis of MS in children, including the role of neuroimaging in the diagnosis of childhood multiple sclerosis.
\end{abstract}

Key words: multiple sclerosis, children, magnetic resonance imaging.

prawidłowych rozpoznań jest jednak znacznie mniejsza niz liczba rzeczywistych zachorowań, co wynika z braku jasnych kryteriów diagnostycznych dla SR i innych chorób demielinizacyjnych występujących w tej grupie wiekowej: jednofazowego, nawracającego oraz wielofazo-

Adres do korespondencii: dr hab. Elżbieta Jurkiewicz, Instytut „Pomnik - Centrum Zdrowia Dziecka”, Al. Dzieci Polskich 20, 04-730 Warszawa, e-mail: e-jurkiewicz@02.pl

Pracę otrzymano: 4.07.2010; przyięto do druku: 20.12.2010 
wego ostrego zapalenia mózgu i rdzenia kręgowego (acute disseminated encephalomyelitis - ADEM), poprzecznego zapalenia rdzenia kręgowego i zapalenia nerwów wzrokowych, nazywanego dawniej chorobą Devica (neuromyelitis optica - NMO), czy odosobnionego zespołu klinicznego (clinically isolated syndrome - CIS).

Trudności diagnostyczne związane są z odrębnościami przebiegu klinicznego oraz różnicami w obrazie rezonansu magnetycznego (RM), które u dzieci odbiegają od obrazu stwierdzanego u dorosłych. Problem dziecięcej formy SR jest bardzo ważny; świadczy o tym liczba artykułów poświęconych temu tematowi, publikowanych w ostatnich latach w renomowanych czasopismach.

Zgodnie z terminologią WHO forma dziecięca (pediatric) SR odnoszona jest do wieku ponizej 10. roku życia, natomiast pacjenci w wieku 10-18 lat kwalifikowani są jako młodzieńcza forma SR. W 2007 r. Międzynarodowa Grupa Badań nad SR u Dzieci (International Pediatric MS Study Group) postanowiła przyjąć jednolitą nazwę „pediatrycznego stwardnienia rozsianego”, w którym mieszczą się poprzednio używane terminy: SR o wczesnym początku i dziecięca forma SR. Grupa ta opracowała i zaproponowała nowe kryteria rozpoznawania SR u dzieci, a także kryteria rozpoznawania ADEM, nawrotowego i wielofazowego ADEM oraz CIS [1].

Stwardnienie rozsiane to autoimmunizacyjna, zapalna i neurodegeneracyjna choroba OUN o złożonej etiologii, zależnej od czynników genetycznych i środowiskowych. Specyfika SR u dzieci dopiero niedawno została lepiej poznana $[2,3]$, co odzwierciedla gwałtownie zwiększająca się liczba publikacji na ten temat, choć pierwsze opisy SR u dzieci pochodzą z prac Charcota, a pierwszy dobrze udokumentowany przypadek SR u dwuletniego dziecka został opisany już w 1984 r. [4].

Częstość zachorowań na SR jest różna w zależności od szerokości geograficznej, np. w Japonii wynosi 0,8-10/100 000, a w Kanadzie ok. 248/100 000. Wśród tych pacjentów ok. $10 \%$ ma pierwsze objawy choroby przed 16. rokiem życia [3]. Badania niemieckie wskazują, że SR u dzieci do 16. roku życia występuje w naszej strefie klimatycznej z częstością 4-8 przypadków na 100000 osób w populacji ogólnej [4]. Wpływ środowiskowy jest istotny; zauważono, że dzieci migrujące przyswajają sobie stopień ryzyka zachorowania typowy dla miejsca pobytu, a nie miejsca urodzenia [3]. Wśród czynników środowiskowych związanych z wcześniejszym zachorowaniem na SR najczęściej wymienia się niedobór witaminy $\mathrm{D}$ we wczesnym dzieciństwie [6].

Czynniki decydujące o zachorowaniu na SR w wieku dziecięcym nie są ustalone. Istotną rolę odgrywają zapewne czynniki genetyczne, wśród nich określone allele układu HLA, np. HLA-DR15 $[7,8]$. Chorzy na SR znacząco częściej niż populacja ogólna są nosicielami HLA-DRB1*1501, DQA1*0102 oraz DQB1*0602. Badania ponad 900 pacjentów wykazały, że u osób z HLA-DR15 znacznie częściej obserwuje się wczesny początek SR [8-10]. Udokumentowane jest rodzinne występowanie SR - ryzyko wystąpienia u krewnych pierwszego stopnia wynosi $5 \% \mathrm{w}$ porównaniu z $0,2 \%$ w populacji ogólnej [11].

Widoczne są różnice w częstości występowania SR w różnych grupach wiekowych w zależności od płci: w grupie pacjentów dorosłych stosunek kobiet do mężczyzn wynosi $2,5: 1$, natomiast u dzieci $1,45: 1$ (są też dane o większej przewadze płci żeńskiej wśród nastolatków). U dzieci poniżej 10. roku życia ta wyraźna przewaga występowania SR u dziewczynek zanika i wynosi $1,17: 1$, co wiąże się ze stężeniami hormonów w okresie przed dojrzewaniem [3]. W najmłodszej grupie pacjentów, poniżej 6. roku życia, chłopcy chorują z tą samą częstością co dziewczęta lub nawet nieco częściej [12].

Stwardnienie rozsiane $\mathrm{u}$ dzieci ma niemal zawsze przebieg nawracająco-zwalniający; jedynie u 2,3\% pacjentów, i to wyłącznie u mających ponad 13 lat, SR przebiega od początku postępująco [13]. Pierwsze objawy choroby to najczęściej niedowłady i objawy uszkodzenia układu piramidowego [14], w drugiej kolejności izolowane pozagałkowe zapalenie nerwu wzrokowego lub izolowane objawy uszkodzenia pnia mózgu [15-18]. U 8-39\% dzieci, zwłaszcza młodszych, pierwszy rzut SR ma cechy rozsianego zapalenia mózgu i rdzenia, z charakterystycznymi dla zapalenia mózgu objawami w postaci zaburzeń świadomości, drgawek, bólu głowy, nudności i wymiotów $[12,17,18]$. W grupie najmłodszych pacjentów, poniżej 6. roku życia, do najczęstszych pierwszych objawów SR należą ataksja i padaczka $[12,19]$. Częstym objawem SR u dzieci są zaburzenia funkcji poznawczych [20]. U dzieci choroba cechuje się nieco wolniejszym przebiegiem niż u osób dorosłych, jednak ze względu na zachorowanie w młodszym wieku, niższy jest wiek występowania poszczególnych stadiów niepełnosprawności [14]. Częstość rzutów u dzieci jest statystycznie większa niż u pacjentów dorosłych [17].

Pierwsze opracowane kryteria rozpoznania SR uwzględniały tylko osoby dorosłe. Obowiązujące w latach 80. i 90. ubiegłego wieku kryteria Posera uniemożliwiały praktycznie rozpoznanie SR u pacjenta poniżej 10. roku życia [21]. Na podstawie wprowadzonych w 2000 r. kryteriów McDonalda SR poniżej 
Tabela 1. Kryteria rozpoznania stwardnienia rozsianego w badaniu za pomoca rezonansu magnetycznego u dorosłych oraz u dzieci [27]

Table 1. Magnetic resonance diagnostic criteria for multiple sclerosis in adults and in children [27]

\begin{tabular}{|lll|}
\hline $\begin{array}{l}\text { Kryteria Mc Donalda, uwzględniające } \\
\text { kryłeria Barkhofa i Tintoré }\end{array}$ & Kryteria KIDMUS z 2004 roku & $\begin{array}{l}\text { Uaktualnione kryłeria KIDMUS } \\
\text { z 2008 roku }\end{array}$ \\
\hline $\begin{array}{l}\text { co najmniej 9 zmian w obrazach } \\
\text { T2-zależnych lub co najmniej jedna } \\
\text { zmiana wzmacniająca się po podaniu } \\
\text { środka kontrastowego }\end{array}$ & $\begin{array}{l}\text { co najmniej jedna zmiana } \\
\text { prostopadła do długiej } \\
\text { osi ciała modzelowatego }\end{array}$ & $\begin{array}{l}\text { pięć lub więcej zmian o charakterze } \\
\text { demielinizacyjnym }\end{array}$ \\
\hline $\begin{array}{l}\text { co najmniej } 3 \text { zmiany położone } \\
\text { okołokomorowo }\end{array}$ & $\begin{array}{l}\text { obecność dobrze odgraniczonych } \\
\text { zmian }\end{array}$ & $\begin{array}{l}\text { co najmniej dwie zmiany położone } \\
\text { okołokomorowo }\end{array}$ \\
\hline $\begin{array}{l}\text { co najmniej jedna zmiana położona } \\
\text { podkorowo }\end{array}$ & & co najmniej jedna zmiana w pniu mózgu \\
\hline $\begin{array}{l}\text { co najmniej jedna zmiana położona } \\
\text { podnamiotowo lub w rdzeniu kręgowym }\end{array}$ & & \\
\hline $\begin{array}{l}\text { konieczne stwierdzenie co najmniej trzech } \\
\text { z wymienionych cech }\end{array}$ & $\begin{array}{l}\text { konieczne stwierdzenie obu } \\
\text { wymienionych cech }\end{array}$ & $\begin{array}{l}\text { konieczne stwierdzenie co najmniej dwóch } \\
\text { wymienionych cech }\end{array}$ \\
\hline
\end{tabular}

16. roku życia rozpoznaje się u 3-10,5\% wszystkich pacjentów z tą chorobą [22-25].

Wiadomo jednak, że u 1,5-5\% wszystkich chorych na SR pierwsze objawy występują poniżej 10. roku życia. Choroba może także występować u bardzo małych dzieci - pierwsze objawy SR poniżej 6. roku życia stwierdza się u mniej niz 1\% wszystkich chorych z SR [23-25], choć istnieją także doniesienia o znacznie częstszym, sięgającym 3\%, początku SR w bardzo młodym wieku [12]. Ustalenie pewnego rozpoznania SR u tych pacjentów jest bardzo trudne.

Badaniem obrazowym stosowanym $z$ wyboru jest rezonans magnetyczny (RM). Zgodnie z kryteriami McDonalda, uwzględniającymi również kryteria Barkhofa i Tintoré, obraz RM może dostarczyć danych na temat rozsiania procesu demielinizacji w czasie i umożliwić u dorosłych rozpoznanie SR przed wystąpieniem klinicznych objawów drugiego rzutu SR $[26,27]$. Stosowane wcześniej kryteria McDonalda wykazywały dużą czułość (74\%) i swoistość (86\%) w rozpoznawaniu SR w grupie osób dorosłych, natomiast retrospektywne ich przełożenie na pediatryczną formę SR nie dało zachęcających wyników $[28,29]$. Kryteria te nie są wystarczająco czułe i nie znajdują zastosowania dla dzieci, zwłaszcza poniżej 10. roku życia, ze względu na mniejszą liczbę zmian typowych, położonych w typowych miejscach oraz większą liczbę ognisk atypowych (dużych i guzopodobnych - tumefactive) [30]. Wykazano, że tylko nieco ponad połowa dzieci z pewnym klinicznie SR spełnia rezonansowe kryteria rozpoznania choroby, a w grupie pacjentów poniżej 10. roku życia odsetek ten nie przekracza $27 \%[25,30]$.
$\mathrm{Z}$ nieco lepszym efektem stosowane były kryteria Barkhofa: u dzieci powyżej 10. roku życia czułość wynosiła $80 \%$, ale u dzieci poniżej 10 . roku życia tylko $27 \%$. To sugeruje, że obraz RM u dzieci poniżej 10. roku życia jest inny niż u dzieci starszych i młodych dorosłych (pacjentów przed i po okresie dojrzewania) $[2,30]$. Uważa się, że wynika to z krótszego czasu trwania choroby i w związku z tym mniejszego nagromadzenia zmian demielinizacyjnych [29].

W ostatnich latach zauważalny jest ogromny postęp w diagnostyce SR u dzieci. W 2004 i 2007 r. opracowano odrębne kryteria RM dla SR u dzieci (kryteria KIDMUS). Kryteria te, choć bardzo swoiste, cechowały się jednak stosunkowo małą czułością - ok. 47\% [1,31].

Opracowane w 2008 r. nowe kryteria rozpoznawcze, które cechują się dużą czułością (85\%) i bardzo dużą swoistością (98\%), przedstawiono w tab. 1. [28].

\section{Obraz rezonansu magnetycznego mózgu dzieci chorych na stwardnienie rozsiane}

Cechy obrazu RM pozwalające na rozpoznanie SR $\mathrm{u}$ dorosłych są dobrze poznane, a aktualnie obowiązujące kryteria McDonalda uwzględniające kryteria Barkhofa i Tintoré pozwalają w większości przypadków na rozpoznanie choroby. Natomiast cechy RM swoiste dla SR w pediatrycznej grupie wiekowej nie sa niestety ogólnie znane. Zmiany demielinizacyjne widoczne w badaniu RM mózgu u dzieci chorych na SR mogą istotnie odbiegać od zmian opisywanych 
u pacjentów dorosłych. Bardzo często spotykane są ogniska wykazujące inną niż u dorosłych wielkość, morfologię, intensywność sygnału oraz lokalizację. Dlatego obraz zmian nie spełnia kryteriów McDonalda pod względem liczby ognisk oraz ich lokalizacji w miejscach typowych dla wymienionych kryteriów.

Typowe dla SR patologiczne ogniska są hiperintensywne w obrazach T2-zależnych, w tym w sekwencji FLAIR, i jako takie występują w obu grupach wiekowych chorych, u dzieci jednak często nie mają charakterystycznego owalnego kształtu.

Zmiany hipointensywne w obrazach $\mathrm{T} 1$-zależnych (często spotykane u dorosłych) są rzadko obserwowane u dzieci. Takie ogniska w badaniu RM wykonanym przy pierwszym rzucie demielinizacji w badaniu prowadzonym przez grupę KIDMUS obserwowano jedynie w $62 \%$ przypadków dzieci [31]. U osób dorosłych utrzymujące się ogniska hipointensywne w obrazie T1-zależnym są wskaźnikiem przewlekłego procesu demielinizacyjnego. Wydaje się, że u dzieci, u których często zmiany te wycofują się, hipointensywne ogniska mogą mieć inne znaczenie (mogą wynikać jedynie z obrzęku wokół blaszek) [30].

Klasycznie zmiany demielinizacyjne mają tendencję do lokalizacji w okolicach okołokomorowych oraz podkorowych [32]. W przeciwieństwie do osób dorosłych, u dzieci obserwuje się znacząco częstsze występowanie

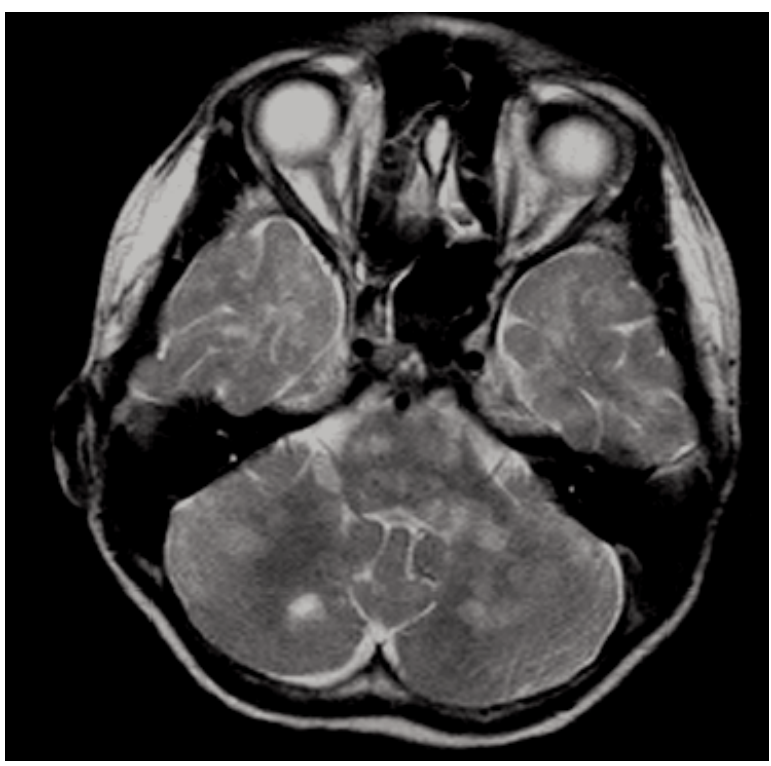

Ryc. 1. RM mózgu - obraz T2-zależny w sekwencii FSE (chłopiec w wieku 10 lat). Liczne ogniska w obrębie mostu, obustronnie konarów móżdżku i istoty białei półkul móżdżku, z przewaga po stronie lewej

Fig. 1. MRI of the brain, T2-weighted image in FSE sequence (10-year-old boy). Numerous lesions are seen in the pons, in both cerebellar peduncles and in the white matter of cerebellar hemispheres. More plaques are seen on the left side zmian w innej lokalizacji: w obrębie pnia mózgu, móżdżku oraz w głębokiej istocie szarej, tj. w jądrach podstawy i we wzgórzu [32] (ryc. 1.).

U 55-66\% chorych na SR o początku w dzieciństwie stwierdza się występowanie ognisk olbrzymich (giant form), większych niż $20 \mathrm{~mm}$, którym często towarzyszy wyraźny obrzęk. W obrębie zmian mogą być widoczne torbiele rzekome, związane ze zmniejszeniem objętości istoty białej mózgu [34,35] (ryc. 2.).

Spotykane są także rozległe zmiany, którym towarzyszy efekt masy oraz obrączkowate wzmocnienie. Może dojść do krwawienia, a także wytworzenia się ognisk martwicy. Takie rzekomoguzowe ogniska $z$ towarzyszącym obrzękiem i efektem masy mogą zajmować cały płat lub nawet półkulę mózgu [32,36,37]. Zmiany demielinizacyjne u dzieci imitujące swoją morfologia guzy są czasami przyczyną znaczących pomyłek diagnostycznych $[38,39]$. Należy pamiętać o tej formie zmian demielinizacyjnych u dzieci, gdyż pomyłki mogą prowadzić do wykonania niepotrzebnej biopsji mózgu [3].

W badaniach osób dorosłych środek kontrastowy stosowany jest bardzo często w celu wykazania aktywnych ognisk demielinizacyjnych. W grupie pacjentów dorosłych z pierwszym rzutem choroby u ok. $52 \%$ osób wykazano obecność wzmacniających się ognisk [40]. Natomiast w publikowanych opracowaniach badań dziecięcych

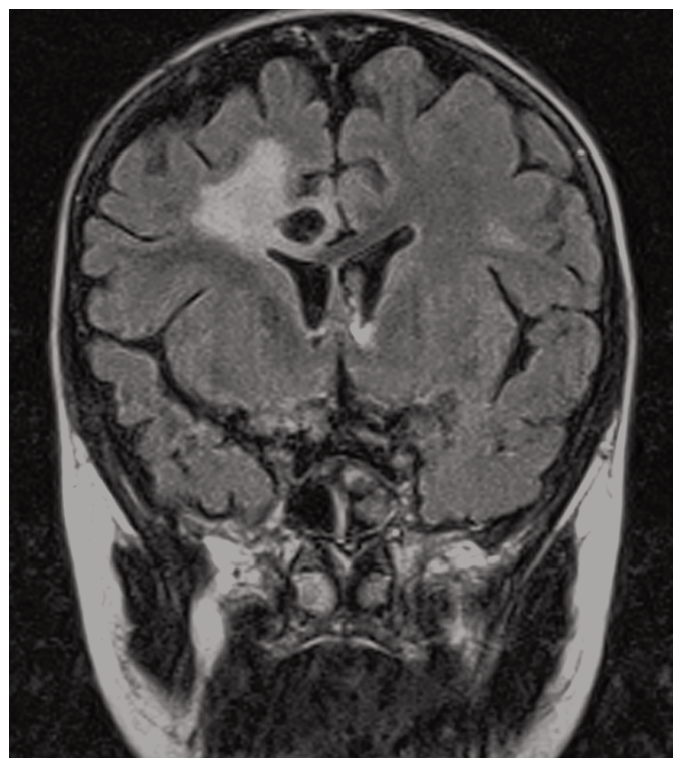

Ryc. 2. RM mózgu - obraz w sekwencii FLAIR FSE (chłopiec w wieku 11 lat). Duży, nieregularny obszar zajmujacy istotę białą i prawą część ciała modzelowatego. W części ogniska zmiana torbielowata. Nieznaczny efekt masy

Fig. 2. MRI of the brain, FSE FLAIR (11-year-old boy). Large, irregular lesion involving white matter and right part of the corpus callosum with cystic lesion. Slight mass effect is present 


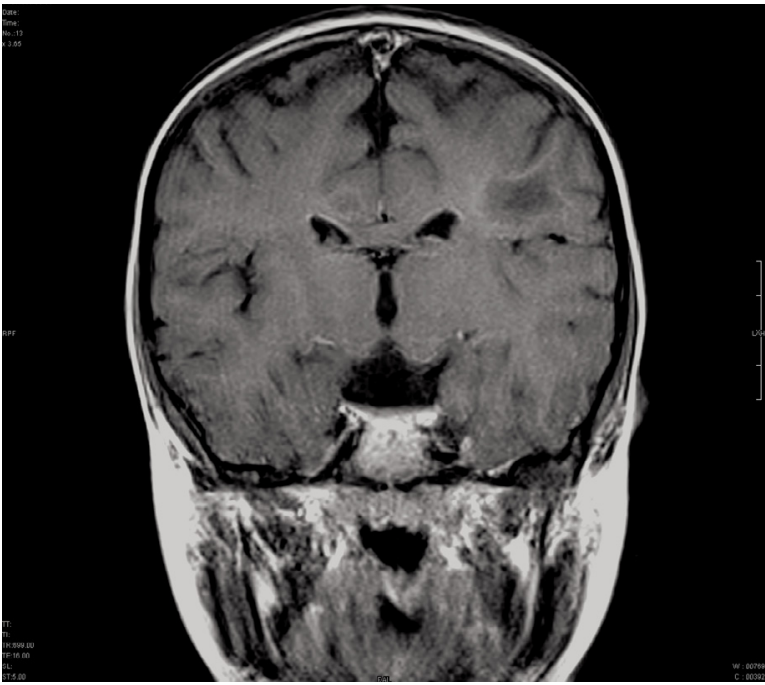

Ryc. 3. RM mózgu - obraz Tl-zależny w sekwencii SE (chłopiec w wieku 10 lat). Słabe, brzeżne wzmocnienie wokół dużego hipointensywnego ogniska Fig. 3. MRI of the brain T7-weighted image in SE sequence (10-year-old boy). Weak enhancement around large hypointense lesion

środek kontrastowy podawany był rzadko. W opublikowanych badaniach wzmocnienie było obserwowane u 24\% dzieci z rozpoznaniem $\mathrm{SR}$, ale tylko połowie badanych podano środek kontrastowy [32]. Obserwowano różnorodny wzorzec wzmocnienia kontrastowego: guzkowe, rozlane guzkowe, punktowe, bezkształtne i niekompletne obrączkowate (ryc. 3.). Zgodnie jednak z publikowanymi danymi w przypadkach badań jednofazowych, wyznacznikiem ostrej fazy demielinizacyjnej u dzieci jest obecność bardzo dużych ognisk otoczonych wyraźną strefą obrzęku - tumefactive lesions [29,38].

Podkreślenia wymaga obraz RM w przypadkach SR u dzieci bardzo młodych, poniżej 10. roku życia, który wyraźnie różni się od typowego obrazu spotykanego w wieku późniejszym. Pierwszy rzut choroby może wystąpić jako masywne, rozlane zmiany o nieostrych granicach, obustronnie zajmujące istotę białą, które mogą sugerować rozpoznanie leukodystrofii [31] (ryc. 4.).

Rozlane zmiany demielinizacyjne określano dawniej mianem choroby Schildera - obecnie termin ten jest zarezerwowany dla bardzo rzadko występującego mielinoklastycznego stwardnienia rozlanego mózgu [41]. $\mathrm{W}$ badaniach dzieci młodszych przed okresem dojrzewania wykazano znacznie mniejszą liczbę oraz wielkość ognisk hiperintensywnych w obrazach T2-zależnych w porównaniu z nastolatkami [42].

Niewielka liczba doniesień dotyczących badań i obecności zmian w rdzeniu kręgowym u dzieci nie pozwoliła na włączenie takich ognisk do kryteriów dia-

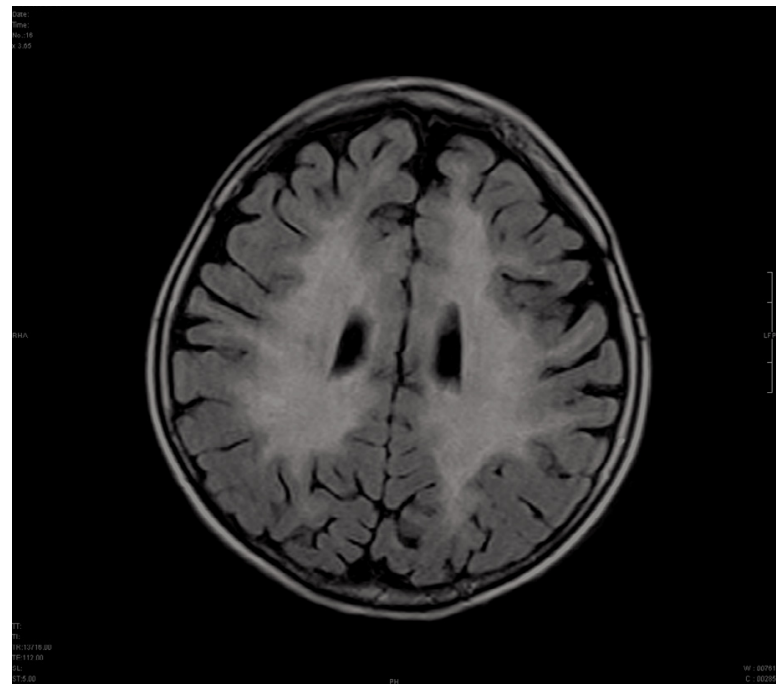

Ryc. 4. RM mózgu - obraz w sekwencii FLAIR FSE (chłopiec w wieku 7 lat). Rozległy obszar symetrycznie zaimuiący istołę białą pókuu mózgu

Fig. 4. MRI of the brain, FSE FLAIR (7-year-old boy). Diffuse bilateral, symmetrical involvement of white matter

gnostycznych. Zanik rdzenia jest objawem rzadko stwierdzanym u dzieci, znacząco częściej występuje u dorosłych [40].

W odróżnieniu od wytycznych dla pacjentów dorosłych, grupa KIDMUS proponuje wykonanie kontrolnego badania RM u dzieci 6 tygodni po pierwszym incydencie demielinizacyjnym, w celu potwierdzenia rozsiania procesu w czasie $[22,30]$.

Specyfikę obrazu rezonansu magnetycznego OUN dzieci chorych na SR przedstawiono w tab. 2.

Ze względu na brak typowego obrazu SR u dzieci w różnicowaniu należy brać pod uwagę szeroki wachlarz chorób. Diagnostykę różnicową SR w pediatrycznej grupie wiekowej, uwzględniającą najczęściej występujące jednostki chorobowe, przedstawiono w tab. 3 .

\section{Zaawansowane techniki rezonansu magnetycznego w obrazowaniu zmian w przebiegu stwardnienia rozsianego}

Nowoczesne metody badań obrazowych za pomocą RM umożliwiają nie tylko ocenę ewentualnych zmian strukturalnych, ale także funkcji mózgu. Wprowadzenie zaawansowanych technik rezonansowych, takich jak spektroskopia RM (MRS), badania perfuzyjne (PWI), techniki dyfuzyjne na czele $\mathrm{z}$ tensorem dyfuzji, traktografią i anizotropią frakcjonowaną, stało się możliwe 
Tabela 2. Specyfika obrazu rezonansu magnetycznego u dzieci chorych na stwardnienie rozsiane

Table 2. MRI characteristics of paediatric multiple sclerosis

\begin{tabular}{|l|}
\hline $\begin{array}{l}\text { Większość ognisk hiperintensywnych w obrazach T2-zależnych ma nieostre zarysy, pozbawione są charakterystycznego } \\
\text { dla dorosłych owalnego kształtu }\end{array}$ \\
\hline $\begin{array}{l}\text { Zauważa się znacznie częstszą lokalizację ognisk w obszarze podnamiotowym (w tym w pniu mózgu!), przy czym zjawisko to } \\
\text { jest częstsze u chłopców }\end{array}$ \\
\hline Znacząco częściej, zwłaszcza u dzieci młodszych, stwierdza się zajęcie jąder podstawy i wzgórz \\
\hline U części pacjentów stwierdza się atypowe, duże ogniska guzopodobne, sugerujące obecność zmiany rozrostowej \\
\hline Ponad 65\% pacjentów pediatrycznych ma przynajmniej jedną zmianę większą niż $20 \mathrm{~mm}$ \\
\hline $\begin{array}{l}\text { U dzieci młodszych rozległe zajęcie istoty białej półkul mózgu może sugerować choroby metaboliczne: leukodystrofie, } \\
\text { choroby mitochondrialne }\end{array}$ \\
\hline
\end{tabular}

dzięki nowoczesnym aparatom o dużym natężeniu pola magnetycznego (1,5 lub 3 T). Urządzenia te charakteryzują się znacznie większą czułością i dużym stosunkiem sygnału do szumu. Coraz większa liczba badań naukowych udowadnia przydatność tych nowoczesnych technik rezonansowych $\mathrm{w}$ diagnostyce i monitorowaniu SR [42-44]. Niektóre z nich, takie jak MRS czy obrazowanie tensora dyfuzji, stanowią coraz częściej nieodłączną część rutynowego badania RM, a także ogromną pomoc $\mathrm{w}$ diagnostyce różnicowej zmian demielinizacyjnych u dzieci. Ogromne zainteresowanie wzbudza zastosowanie wyżej wymienionych technik w wykrywaniu zaburzeń w obrębie prawidłowo wyglądającej istoty białej i szarej (normal-appearing white matter/gray matter) $[45,46]$. Szczególnie istotne jest wykrycie takich nieprawidłowości dla prognozowania ryzyka rozwoju SR u pacjentów z CIS [47].

Spektroskopia wodorowa (HMRS) to metoda pozwalająca zauważyć zmianę stężenia metabolitów w obszarach wykazujących nieprawidłowy sygnał w badaniu obrazowym, jak też w prawidłowo wyglądającej istocie białej i szarej. W diagnostyce SR najistotniejsze są dwa metabolity: N-acetyloasparaginian (NAA) - marker żywotności neuronalnej, oraz mioinozytol (Ins, mI) wyznacznik aktywności komórek glejowych, zlokalizowany w komórkach astrogleju. U pacjentów z potwierdzonym SR zmniejszenie zawartości NAA i zwiększenie zawartości mIns widoczne jest zarówno w obrębie plak demielinizacyjnych, jak też w prawidłowo wyglądającej tkance. Zmiany w stężeniach metabolitów związane są ze zniszczeniem aksonów oraz wzrostem aktywności komórek glejowych $[48,49]$.

$\mathrm{W}$ najpopularniejszych skanerach o polu 1,5 T stosunkowo mały zakres przesunięć chemicznych utrudnia czasami rozdzielenie poszczególnych pików rezonansowych. Natomiast w aparatach o większym polu magnetycznym (3 T), charakteryzujących się znacząco większą
Tabela 3. Różnicowanie stwardnienia rozsianego

Table 3. Differential diagnosis of multiple sclerosis

\begin{tabular}{|c|c|}
\hline \multirow[t]{5}{*}{$\begin{array}{l}\text { zmiany } \\
\text { demielinizacyjne }\end{array}$} & $\begin{array}{l}\text { ostre rozsiane, wielofazowe lub nawrotowe } \\
\text { zapalenie mózgu i rdzenia kręgowego }\end{array}$ \\
\hline & zapalenie nerwów wzrokowych \\
\hline & zapalenie poprzeczne rdzenia kręgowego \\
\hline & $\begin{array}{l}\text { poprzeczne zapalenie rdzenia kręgowego } \\
\text { i zapalenie nerwów wzrokowych }\end{array}$ \\
\hline & odosobniony zespół kliniczny \\
\hline \multirow[t]{3}{*}{ zmiany zapalne } & toczeń układowy \\
\hline & sarkoidoza \\
\hline & zespół antyfosfolipidowy \\
\hline \multicolumn{2}{|c|}{ choroby genetyczne/ leukodystrofie } \\
\hline metaboliczne & choroby mitochondrialne \\
\hline \multirow[t]{4}{*}{ choroby naczyń } & zapalenie naczyń mózgowych \\
\hline & migrena \\
\hline & mózgowa autosomalna dominująca arteriopatia \\
\hline & z podkorowymi zawałami i leukoencefalopatią \\
\hline \multirow{3}{*}{$\begin{array}{l}\text { nowotwory } \\
\text { ośrodkowego } \\
\text { układu nerwowego }\end{array}$} & chłoniaki \\
\hline & białaczki \\
\hline & gwiaździaki \\
\hline \multirow[t]{5}{*}{ zakażenia } & neuroborelioza \\
\hline & gruźlica \\
\hline & kiła \\
\hline & podostre stwardniejące zapalenie mózgu \\
\hline & zakażenie HIV \\
\hline
\end{tabular}

rozdzielczością czasową i przestrzenną, możliwe jest otrzymanie widma spektroskopowego o przesunięciu chemicznym pozwalającym na identyfikację i precyzyjne wyodrębnienie piku glutaminianu, którego wzrost stwierdzono zarówno w aktywnych zmianach, jak i niezmienionej istocie białej. Ponieważ uważa się, że glutaminian jest czynnikiem neurotoksycznym, jego zwiększona ilość wykrywana w HMRS może być odpowiedzialna za uszkodzenie aksonów [50]. Aparaty o dużym polu 
magnetycznym pozwalają również na wykrywanie zmian demielinizacyjnych niewidocznych w badaniach wykonanych z wykorzystaniem słabszej aparatury, nawet przy zastosowaniu technik konwencjonalnych.

Obrazowanie zależne od dyfuzji wody (diffusionweighted imaging - DWI), a w szczególności obrazowanie tensora dyfuzji (diffusion tensor imaging - DTI), podobnie jak MRS, wykorzystuje się do analizy zmienionych obszarów oraz prawidłowo wyglądającej istoty białej i szarej mózgu [51,52]. Zmiany zapalne prowadzące do poszerzenia naczyń, wzrost przepuszczalności śródbłonka, wysięk płynu i migracje leukocytów zmieniają wzorzec dyfuzji. Obrzęk komórek (wraz ze wzrostem ilości wody wewnątrzkomórkowej) wpływa na zmniejszenie przestrzeni zewnątrzkomórkowej i obniża anizotropię, a zwiększa dyfuzyjność. U podstaw nieprawidłowości w obrazie dyfuzyjnym u chorych na SR leży demielinizacja i utrata aksonów. Technika DTI wykazuje ogromną czułość w wykrywaniu strukturalnych zmian w pozornie niezmienionym mózgu: zmiany zapalne i glioza powodują ograniczenie ruchów molekuł wody. Badania sekcyjne wykazywały obecność rozległych zniszczeń mózgu, które były niewidoczne w standardowym obrazowaniu RM, nawet przy zastosowaniu aparatów o dużym polu magnetycznym [53]. W badaniach opublikowanych w 2005 r. zauważono obniżenie anizotropii frakcjonowanej (fractional anisotropy - FA) spowodowane dezorganizacją struktury tkankowej i podwyższenie średniej dyfuzyjności (mDTI) wywołane zniszczeniem aksonów i otoczek mielinowych, przy czym zmiany takie wystąpiły zarówno w zmienionych, jak i niezmienionych obszarach mózgu [54,55]. Podwyższoną wartość rzeczywistego współczynnika dyfuzji (apparent diffusion coefficent - ADC) zaobserwowano w niezmienionej istocie białej, w tych miejscach, w których po 6 miesiącach pojawiły się świeże ogniska wzmacniajace się po podaniu środka kontrastowego. Objaw ten wiązany jest $\mathrm{z}$ bardzo wczesnym uszkodzeniem integralności bariery krew-mózg i napływem komórek zapalnych prowadzącym do mikrostrukturalnych nieprawidłowości w istocie białej, zanim uwidocznią się w obrazowaniu klasycznym [56]. Wstępne badania pokazują przydatność DTI w ocenie deficytów mowy, uwagi i pamięci u chorych na SR. Zauważono korelacje pomiędzy średnią dyfuzji niezmienionej istoty białej a stopniem uszkodzenia funkcji poznawczych u tych pacjentów [57].

Wszystkie te techniki, a zwłaszcza DTI, znajdują coraz częściej zastosowanie w diagnostyce SR u dzieci [58]. Szczególnie przydatne mogą być dla prognozo- wania rozwoju SR u dzieci po pierwszym epizodzie choroby demielinizacyjnej, co ma ogromne znaczenie dla wdrożenia odpowiedniego postępowania leczniczego.

W ostatnich latach wiele publikacji porusza temat wykorzystania funkcjonalnego badania RM (fMR) w SR $[45,59]$. Szczególne zainteresowanie budzi możliwość obiektywizacji objawów ubytkowych i ewentualne zastosowanie tej techniki w próbach klinicznych nowych leków w SR. Niewątpliwie jednak technika ta pozwala na nowoczesne i głębsze niż do tej pory poznanie zaburzeń funkcji poznawczych w SR [45]. Zaburzenia funkcji poznawczych w przebiegu SR stwierdza się istotnie częściej u dzieci niż u dorosłych [3], stanowią one także bardziej złożony problem $z$ uwagi na równolegle zachodzący rozwój dziecka. Możliwość obiektywizacji tych zaburzeń stanowi cenne narzędzie w postępowaniu $z$ dziećmi chorymi na SR. Funkcjonalny rezonans magnetyczny stwarza także unikalną możliwość obrazowania plastyczności mózgu, co - jak wynika z najnowszych badań - ma ogromne znaczenie w SR.

\section{Oświadczenie}

Wszystkie ryciny zaprezentowane w pracy pochodza z Pracowni Rezonansu Magnetycznego IPCZD - badania RM pacjentów Kliniki Neurologii Instytutu. Autorki zgłaszają brak konfliktu interesów.

\section{Piśmiennictwo}

1. Krupp L.B., Banwell B., Tenembaum S. Consensus definitions proposed for pediatric multiple sclerosis and related disorders. Neurology 2007; 68: S7-S12.

2. Chabas D., Strober J., Waubant E. Pediatric multiple sclerosis. Curr Neurol Neurosci Rep 2008; 8: 434-441.

3. Banwell B.L. Pediatric multiple sclerosis. Curr Neurol Neurosci Rep 2004; 4: 245-252.

4. Bejar J.M., Ziegler D.K. Onset of multiple sclerosis in a 24month-old child. Arch Neurol 1984; 41: 881-882.

5. Kampman M.T., Brustad M. Vitamin D: a candidate for the environmental effect in multiple sclerosis - observations from Norway. Neuroepidemiology 2008; 30: 140-146.

6. Dyment D.A., Ebers G.C., Sadovnick A.D. Genetics of multiple sclerosis. Lancet Neurol 2004; 3: 104-110.

7. Masterman T., Ligers A., Olsson T. i wsp. HLA-DR15 is associated with lower age onset in multiple sclerosis. Ann Neurol 2000; 48: 211-219.

8. Barcellos L.F., Oksenbrg A.B., Begovich A.B. i wsp. HLADR2 dose effect on susceptibility to multiple sclerosis and influence on disease course. Am J Hum Genet 2003; 7: 710-716.

9. Dyment D.A., Sadovnick A.D., Ebers G.C. i wsp. Genetics of multiple sclerosis. Hum Mol Genet 1997; 6: 1693-1698. 
10. Jan M.M. Childhood multiple sclerosis. J Pediatr Neurol 2005; 3: 131-136.

11. Ruggieri M., Polizzi A., Pavone L. i wsp. Multiple sclerosis in children under 6 years of age. Neurology 1999; 53: 478-484.

12. Renoux C., Vukusic S., Mikaeloff Y. i wsp. Natural history of multiple sclerosis with childhood onset. N Eng J Med 2008; 356: 2603-2613.

13. Ferreira L., Machado M.I., Dantas M.J. i wsp. Pediatric multiple sclerosis. Arch Neuropsichiatr 2008; 66: 665-670.

14. Renoux C., Vukusic S., Mikaeloff Y. i wsp. Natural history of multiple sclerosis with childhood onset. $N$ Engl J Med 2007; 21: 2603-2613.

15. Ness J.M., Chabas D., Sadovnick A.D. i wsp. Clinical features of children and adolescents with multiple sclerosis. Neurology 2007; 68: 37-45.

16. Ghezzi A. Clinical characteristics of multiple sclerosis with early onset. Neurol Sci 2004; 25: 336-339.

17. Forresster M.B., Coleman L., Kornberg A.J. Multiple sclerosis in childhood: clinical and radiological features. J Child Neurol 2009; 24: 56-62.

18. Sokic D., Stojsavlevic N., Drulevic J. i wsp. Seizures in multiple sclerosis. Epilepsia 2001; 42: 72-79.

19. Montiel-Nava C., Pena J., Gonzalez-Pernia S. i wsp. Cognitive impairment in children with multiple sclerosis. Mult Scler 2009; 15: 266-268.

20. Poser C.M., Paty D.W., Scheinberg L. i wsp. New diagnostic criteria for multiple sclerosis: guidelines for research protocols. Ann Neurol 1983; 13: 227-230.

21. McDonald W.I., Compston D.A.S., Edan G. i wsp. Recommended diagnostic criteria for multiple sclerosis: guidelines from the International Panel on the Diagnosis of Multiple Sclerosis. Ann Neurol 2001; 50: 121-127.

22. Pohl D. Epidemiology, immunopathogenesis and management of pediatric central nervous system inflammatory demyelinating conditions. Curr Opin Neurol 2008; 21: 366-372.

23. Banwell B., Kennedy J., Sadovnick D. i wsp. Incidence of acquired demyelination of the CNS in Canadian children. Neurology 2009; 72: 232-239.

24. Ruggieri M., Ianetti P., Polizzi A. i wsp. Multiple sclerosis in children under 10 years of age. Neurol Sci 2004; 25: 326-335.

25. Barkhof F., Filippi M., Miller D.H. i wsp. Comparison of MRI criteria at first presentation to predict conversion to clinically definite multiple sclerosis. Brain 1997; 120: 2059-2069.

26. Tintoré M., Rovira A., Martínez M.J. i wsp. Isolated demyelinating syndromes: comparison of different MRI criteria to predict conversion to clinically definite multiple sclerosis. Am J Neuroradiol 2000; 21: 702-706.

27. Callen D.J.A., Shroff M.M., Branson H.M. i wsp. MRI in the diagnosis of pediatric multiple sclerosis. Neurology 2009; 72: 961-967.

28. Hahn C.D., Shroff M.M., Blaser S. i wsp. MRI criteria for multiple sclerosis: evaluation in a pediatric cohort. Neurology 2004; 62: 806-808.

29. Banwell B., Shroff M., Ness J.M. i wsp. MRI features of pediatric multiple sclerosis. Neurology 2007; 68: S46-S53.
30. Mikaeloff Y., Adamsbaum C., Husson B. i wsp. MR prognostic factor relapse after acute CNS inflammatory demyelination in childhood. Brain 2004; 127: 1942-1947.

31. Triulzi F. Neuroradiology of multiple sclerosis in children. Neurol Sci 2004; 25: S340-S343.

32. Dale R.C., de Sousa C., Chong W.K. i wsp. Acute disseminated encephalomyelitis, multiphasic disseminated encephalomyelitis and multiple sclerosis in children. Brain 2000; 123: 2407-2422.

33. Danquette P., Murray T.J., Pleines J. i wsp. Multiple sclerosis in childhood: clinical profile in 125 patients. J Pediatr 1987; 111: 359-363.

34. Galluci M., Caulo M., Cerone G. i wsp. Acquired inflammatory white matter diseases. Childs Nerv Syst 2001; 17: 202-210.

35. Al-Bunyan M.A. Tumor-like presentation of multiple sclerosis. Audi Med 2000; 21: 393-395.

36. McAdam L., Blaser S., Banwell B. Pediatric tumefactive demyelination: case series and review of the literature. Pediatr Neurol 2002; 26: 18-25.

37. Jamroz-Wisniewska A., Janczarek M., Belniak E. i wsp. Tumorlike lesions in multiple sclerosis. Neurol Neurochir Pol 2008; 2: 161-167.

38. Wang C.H., Walsh K. Multiple ring-enhancing lesions in child with relapsing multiple sclerosis. J Child Neurol 2002; 17: 69-72.

39. Korteweg T., Tintoré M., Uitdehaag B. i wsp. MRI criteria for dissemination in space in patients with clinically isolated syndromes: a multicentre follow-up study. Lancet Neurol 2006; 5: 221-227.

40. Balassy C., Bernert G., Wober-Bingol C. i wsp. Long-term MRI observations in childhood-onset relapsing-remitting multiple sclerosis. Neuropediatrics 2001; 32: 28-37.

41. Chabas D., Castillo-Trivino T., Mowry E.M. i wsp. Vanishing MS T2-bright lesions before puberty: a distinct MRI phenotype? Neurology 2008; 71: 1090-1093.

42. Fink F., Klein J., Lanz M. i wsp. Comparison of diffusion tensorbased tractography and quantified brain atrophy for analyzing demyelination and axonal loss in MS. Neuroimaging 2010;20: 334-344.

43. Wattjes M.P., Barkhof F. High field MRI in the diagnosis of multiple sclerosis: high field-high yield? Neuroradiology 2009; 5: 279-292.

44. Pichiecchio A., Tavazzi E., Maccabelli G. i wsp. What insights have new imaging techniques given into aggressive forms of MSdifferent forms of MS or different from MS? Mult Scler 2009; 3: 285-293.

45. Filippi M., Agosta F. Magnetic resonance techniques to quantify tissue damage, tissue repair, and functional cortical reorganization in multiple sclerosis. Prog Brain Res 2009; 175: 465-482.

46. Siger-Zajdel M., Selmaj K. Proton magnetic resonance spectroscopy of normal appearing white matter in asymptomatic relatives of multiple sclerosis patients. Eur J Neurol 2006; 3: 296-298.

47. Miller D.H., Thompson A.J., Filippi M. Magnetic resonance study of abnormalities in the normal appearing white and grey matter in multiple sclerosis. J Neurol 2003; 250: 1407-1419. 
48. Chard D.T., Griffin C.M., McLean M.A. i wsp. Brain metabolite changes in cortical grey and normal-appearing white matter in clinically early relapsing remitting multiple sclerosis. Brain 2002; 125: 2342-2352.

49. Tedeschi G., Bonavita S., McFarland H.F. i wsp. Proton MR spectroscopic imaging in multiple sclerosis. Neuroradiology 2002; 44: 37-42.

50. Srinivasan R., Sailasuta N., Hurd R. i wsp. Evidence of elevated glutamate in multiple sclerosis using magnetic resonance spectroscopy at 3T. Brain 2005; 128: 1016-1025.

51. Mezzapesa D.M., Rocca M.A., Falini A. i wsp. A preliminary diffusion tensor and magnetization transfer magnetic resonance imaging study of early-onset multiple sclerosis. Arch Neurol 2004; 61: 366-368

52. Spalice A., Nicita F., Papetti L. i wsp. Usefulness of diffusion tensor imaging and fiber tractography in neurological and neurosurgical pediatric diseases. Childs Nerv Syst 2010; 26: 995 1002.

53. Geurts J.J., Bö L., Pouwels P.J. i wsp. Cortical lesions in multiple sclerosis: combined postmortem MR imaging and histopathology. AJNR Am J Neuroradiol 2005; 3: 572-577.

54. Rovaris M., Gass A., Bammer R. i wsp. Diffusion MRI in multiple sclerosis. Neurology 2005; 65: 1526-1532.

55. Gallo A., Rovaris M., Riva R. i wsp. Diffusion-tensor magnetic resonance imaging detects normal-appearing white matter damage unrelated to short-term disease activity in patients at the earliest clinical stage of multiple sclerosis. Arch Neurol 2005; 62: 803-808.

56. Ciccarelli O., Werring D.J., Wheeler-Kingshott C.A. i wsp. Investigation of MS normal-appearing brain using diffusion tensor MRI with clinical correlations. Neurology 2001; 56: 926-933.

57. Rovaris M., Iannucci G., Falautano M. i wsp. Cognitive dysfunction in patients with mildly disabling relapsing-remitting multiple sclerosis: an exploratory study with diffusion tensor MR imaging. J Neurol Sci 2002; 195: 103-109.

58. Vishwas M.J., Chitnis T., Pienaar R. i wsp. Tract-based analysis of callosal, projection, and association pathways in pediatric patients with multiple sclerosis: a preliminary study. AJNR Am $J$ Neuroradiol 2010; 31: 121-128.

59. Wegner C., Filippi M., Korteweg T. i wsp. Relating functional changes during hand movement to clinical parameters in patients with multiple sclerosis in a multi-centre fMRI study. Eur $J$ Neurol 2008; 2: 113-122. 